\title{
Reading Trends and Perceptions towards Islamic English Websites as Teaching Materials
}

\author{
Zurina Khairuddin ${ }^{1}$, Azimah Shurfa Mohammed Shukry ${ }^{1} \&$ Nurshafawati Ahmad Sani $^{1}$ \\ ${ }^{1}$ School of English Language Studies, Universiti Sultan Zainal Abidin, Terengganu, Malaysia \\ Correspondence: Zurina Khairuddin, School of English Language Studies, Universiti Sultan Zainal Abidin, \\ 21300 Kuala Terengganu, Terengganu, Malaysia. Tel: 609-668-8062. E-mail: zkzurina@unisza.edu.my
}

Received: April 21, 2014 Accepted: May 28, 2014 Online Published: July 15, 2014

doi:10.5539/elt.v7n8p124 URL: http://dx.doi.org/10.5539/elt.v7n8p124

\begin{abstract}
This paper is a study of the reading trends and perceptions of Muslim Malaysian undergraduate students towards Islamic English websites as pedagogical materials in English language classrooms. Data was collected through a set of questionnaires to 180 students from the International Islamic University Malaysia (IIUM) and Universiti Sultan ZainalAbidin (UniSZA). The findings revealed that the students were self-motivated to read the materials to gain spiritual knowledge and to use the knowledge to deal with personal challenges. It also shows that the students recommend that the materials are used for pedagogical purposes in the learning of the English language. The study proposed that texts that bring enjoyment, inspiration, spiritual knowledge and personal development are used as reading materials in English lessons for Muslim students. This would enhance the motivation to read more whilst improving the proficiency of the English language.
\end{abstract}

Keywords: reading trends, English Islamic websites, teaching materials, perceptions, Malaysian Muslims

\section{Introduction}

A Malaysian Reading Profile Survey conducted in Malaysia in 2010 revealed that Malaysians above the age of ten read an average of eight to twelve books a year (National Library of Malaysia, 2010). Although the study indicates that $93 \%$ of the Malaysians are literate, the reading habits of Malaysians are still considerably low (Imran Ariff, 2010). Adding to this is the fact that Senu (2002, as cited in Imran Ariff, 2010) also found that Malaysians only spend an average of RM50 yearly per family on books. Furthermore, a study conducted by Zurina (2013) on Malaysian secondary school students showed low reading interests particularly in the English language reading materials. Therefore, despite being a literate country, this finding may suggest that pupils are only reading academic-based texts. In other words, Malaysians as a whole do not read for pleasure, nor pursue it as a hobby.

Perhaps the cause of the low interest in reading, especially in the English language, is because the second-language learners do not feel that their values and needs are portrayed in the English language texts. According to Ratnawati, English language materials often carry the Americano-Eurocentric perspective that could be contradictory or incompatible to the beliefs of the Islamic faith (1996, as cited in Adam \& Lallmamode, 2009). A study by McKay (2003) indicated that the ELT/ELS pedagogy materials have always been derived from the cultures of the Inner Circle which are the United Kingdom, United States, Australia, New Zealand and Ireland. But by leaving out and ignoring the cultures of the learners can be a cause for concern for Muslim students if the values in the texts contradict the Islamic beliefs. Hameed (2009, p. 564) offers the following definition of Islamic values: "a set of moral principles and guidance that recognises what is right behaviour from what is wrong or what one should do or not." This is guided by the strict belief in the oneness of God and the true purpose of the creation of man; values that are different from the secular or Christian-based worldview.

Due to the lack of fair portrayal and representation of Islam and Muslims in books, English Muslim views can now be read online where more and more English-speaking Muslim writers, scholars and Islamic organisations are writing on Islamic websites about Islam and discussing issues from the Islamic world view. Aliyu, Mahmud, and Tap (2013, p. 35) defines the term 'Islamic website' as follows: "An Islamic website is widely regarded as an Internet-based site created for and devoted to the service of Islam as a religion and a way of life... whose main objective is to portray the commandments of Allah (SWT) in accordance with the teachings of Prophet Muhammad (SAW)". Comparing the similarities of several Islamic websites in a study, Aliyu, Mahmud and Tap 
(2013) concluded that the Islamic websites shared the following common features: beliefs, ethics, services and values.

It is evident therefore that based on the growing statistics of readership on the Islamic websites, interests towards Islamic writings among young Muslim readers are promising (Ibrahim, Hamzah, Taslim, \& Adnan, 2010; Aliyu, Mahmud, \& Tap, 2013). The popularity could be attributed to its many Islamic online services that are available including the two-way dialogue with Muslims scholars and other Muslims online visitors, educational training, community development programmes and even online marriage prospects (Bunt, 2003; Aliyu, Mahmud, \& Tap, 2013). A survey, involving 246 International Islamic University Malaysia (IIUM) undergraduate students, revealed that the students were attracted to the Islamic ethics promoted online such as beneficence, sincerity, forgiveness, honesty, good model, guidance, enjoining goodness and prohibiting badness, beliefs, piety, wisdom, thankfulness, patience, fairness, truth, mercy, and deep thought (Hameed, 2009 as cited in Aliyu, Mahmud, \& Tap, 2013).

\subsection{Research Problem}

As mentioned by McKay (2003), it is common practice that the culture of the native speakers is integrated into the classroom teaching materials to teach the English language. This is recommended because it is assumed that learning and understanding the language will become more successful (Kachru, 1985, as cited in McKay, 2003). However, it is a problem when other cultures are ignored which could lead to further demotivation to learn a language. Given the fact that Little, Devitt, and Singleton's (1994) assertion that second-language learners prefer to read authentic materials rather than pedagogical texts, well-written Islamic English websites may offer an authentic reading experience to replace the secular reading materials. In other words, for Muslim English learners, Islamic content should be included when teaching the English language. Since Muslim learners have shown high interests towards Islamic writings (Ibrahim, Hamzah, Taslim, \& Adnan, 2010; Aliyu, Mahmud, \& Tap, 2013) the use of these writings in the classroom to teach them English can contribute to a meaningful learning experience. To test this assertion, Muslim students' views and the trend of reading Islamic texts need to be analysed.

In Malaysia, there are three Islamic higher education institutions that promote the integration of Islamic and secular teachings: International Islamic University Malaysia (IIUM), Universiti Sultan ZainalAbidin (UniSZA) and Islamic Sciences University Malaysia (USIM). This study hopes to uncover Muslim students' views towards online English Islamic, its values and messages and its potential of becoming English language teaching materials for Malaysian Muslims. Through this study, recommendations can be made for educators in Islamic institutions to use more Islamic English writings in their classroom. Furthermore, this study also hopes that the findings would reveal whether students with exposure to Islamic English writings support or oppose to the idea of utilising Islamic English texts in their classes.

It is hoped that the Islamic-oriented texts that are presently available in the English language websites may offer an alternative solution to reading English materials that are compatible with the Muslim students whilst they gain English proficiency. Therefore, this study is conducted to identify the reading trends of English Islamic websites amongst Malaysian Muslim youths, determine the Malaysian youths' perceptions towards the texts, and determine their perception of having the English language be taught using materials from the English Islamic websites.

\section{Methodology}

This study employed the quantitative research as it aimed to establish relationships between variables and look for explanations of the basis of such relationship (Fraenkel \& Wallen, 2008).

\subsection{Sample}

For this study, a questionnaire was distributed to 180 students from the International Islamic University Malaysia (IIUM) and the Universiti Sultan Zainal Abidin (UniSZA). The respondents were selected from the Department of English Language where all the Muslim students were required to take additional Islamic courses. Simple random sampling technique was utilised when selecting the sample for this study. This is to ensure that every Department of English Language student has an equal chance of being selected for the study. In selecting the sample, English proficiency was important for understanding the questionnaire. They also needed to have prior exposure to English language and learning as well familiarisation in reading Islamic texts. Both IIUM and UniSZA English Major students fitted this criteria. 


\subsection{Instrument}

This research employed a self-administered survey, so the data were collected through a set of questionnaire. Prior to developing the questionnaire, a pilot study was first conducted on 30 Muslim youths in Malaysia. Their answers determined the proposed list of popular Islamic English websites amongst the Malaysian youths. Their answers also provided a guide to designing and developing the questionnaire for this study. The pilot study was also conducted in order to determine the reliability of the questionnaire and it revealed that the Cronbach Alpha of this questionnaire is .888 . This is more than .7 which indicates that the questionnaire used was reliable.

The questionnaire was divided into three sections; Section A: Demographic; Section B: Current Readings; Section C: Perceptions. For Section B, the topics and sub-themes selected were based on features of Islamic websites that were common and agreed upon from studies by Aliyu, Mahmud, and Tap (2013) and Hameed (2009). It was also selected from a compilation of several popular Islamic English websites as indicated by the participants from the pilot study. The questionnaire also included questions on whether they read to improve their knowledge in Islam and whether they find reading about Islam in the English language a trend. The questions in Section C included questions on whether they feel that reading Islamic writings have improved their relationship with people, studies and motivation level. Other questions also included whether they think that more should be done to publicise Islamic English writings in Malaysian English classes to improve their knowledge in Islam as well as improve their fluency in the English language. The questions employed the Likert Scale of 5 for Strongly Agree to 1 for Strongly Disagree.

\subsection{Methods of Data Collection}

The data was collected in August during the 2013/2014 academic year for a period of one month through a questionnaire that was distributed to 180 students from IIUM and UniSZA. The English-major students were randomly selected and were informed of the study and its reasons and significances. The names of those who received the questionnaire were noted for recordkeeping purposes. The researcher was present at the site in order to explain or answer any question from the students to avoid confusion or misunderstanding. Students were given as much time to answer the questions as needed and the session took approximately 30 minutes. As the researcher was there on site, the questionnaires were collected immediately to ensure that all students submitted the questionnaires. However, out of 180 , only 167 completed questionnaires were able to be analysed as the remaining 13 questionnaires were incomplete.

\subsection{Methods of Data Analysis}

In order to ensure the data analysis was run accurately, the data obtained from the 39-item questionnaire were analysed using a statistical analysis software, Statistical Package for the Social Sciences (SPSS) for Windows v17. It is presented in the form of related statistical measures including frequency, percentages, means and standard deviation.

\section{Results}

After examining the 180 responses from the survey using SPSS 17.0, 13 responses had to be dropped from the sample size because they do not read Islamic English websites as indicated in their response. This meant that they had no opinion of the genre, thus their opinions would be invalid. This meant that only a total of 167 participants from 18 to 29 years of age were used as respondents. The respondents comprised of 126 females $(75.4 \%)$ and $41(25 \%)$ male respondents. The majority of the respondents are Malay $(98.8 \%)$ while the remaining of $1.2 \%$ are Chinese. The respondents' first language varied accordingly where $95.8 \%$ are native speakers of Malay, 3.0\% speak English, and 0.6\% speaks Hokkien and Tamil.

The results from this survey are presented in the tables below. 


\subsection{Students' Current Reading Trends}

Table 1. Ratings according to the types of English Islamic texts

\begin{tabular}{llll}
\hline \multirow{2}{*}{ English Islamic Texts } & Percentage & \\
\cline { 2 - 4 } & Never Read & Less Read & Most Read \\
\hline Articles & 8.4 & 38.3 & 53.3 \\
Websites & - & 50.9 & 49.1 \\
Motivational Books & 11.4 & 52.7 & 35.9 \\
Teaching Books & 15 & 50.9 & 34.1 \\
Academic Books & 23.4 & 43.1 & 33.5 \\
Magazines & 22.2 & 50.9 & 26.9 \\
Historical Books & 23.4 & 55.7 & 21 \\
Fictions & 36.5 & 45.5 & 18 \\
Children Books & 37.1 & 46.7 & 16.2 \\
Comics & 54.5 & 29.3 & 16.2 \\
\hline
\end{tabular}

Table 1 shows the types of English Islamic texts that students read according to genres. More than half of the students rated English Islamic articles as most read. The second most read (49.1\%) is websites. Findings also reveal that children books and comics are the least read Islamic English texts (16.2\%). It is likely due to the small number of available Islamic English children books and comics publications.

Table 2. List of English Islamic websites students read

\begin{tabular}{lll}
\hline \multirow{2}{*}{ English Islamic Websites } & \multicolumn{2}{l}{ Percentage } \\
\cline { 2 - 3 } & No & Yes \\
\hline www.yasminmogahed.com & 68.9 & 31.1 \\
muslimmatters.org & 79.6 & 20.4 \\
productivemuslim.com & 74.9 & 25.1 \\
www.suhaibwebb.com & 73.7 & 26.3 \\
None of the above & 64.7 & 35.3 \\
\hline
\end{tabular}

Table 2 shows a list of the most popular websites according to a previous pilot study conducted on 30 Muslims youths. However, the results elicited from the respondents showed contradictory results. It appears that the respondents were not as exposed to the listed websites as it was assumed. A majority of the respondents (64.7\%) are not familiar with the list with $68.9 \%$ tick NO for www.yasminmogahed.com, $79.6 \%$ for muslimmatters.org, $74.9 \%$ for productivemuslim.com and $73.7 \%$ never read materials from www.suhaibwebb.com. The questionnaire requested that the respondents provide their own list of favourite Islamic English website. 31.14\% of the respondents suggested www.iluvIslam.com as one of their favourite Islamic websites.

Table 3. Factors that influence students to read English Islamic online materials

\begin{tabular}{lll}
\hline & No & Yes \\
\hline Myself & 39.5 & 60.5 \\
Friends & 40.1 & 59.9 \\
Teachers/Lecturers & 40.1 & 59.9 \\
Family & 64.1 & 35.9 \\
Others & 93.4 & 6.6 \\
\hline
\end{tabular}

Table 3 is related to the factors that influence their interest in reading English Islamic online texts. The results show that $60.5 \%$ respondents were self-motivated; whilst friends and lecturers have equal influence (59.9) which indicates that the respondents perceived lecturers' influence is as important as peers' influence.Family influence however appears to be low $(35.9 \%)$. Perhaps because the respondents came from diverse backgrounds, not many 
family members were as exposed to the English Islamic online texts. The questionnaire allowed them the option of stating other influences. Only $6.6 \%$ wrote the following: assignment, work, curiosity and social network websites.

Table 4. Frequency of reading English Islamic websites per week

\begin{tabular}{ll}
\hline & Percentage \\
\hline Every Day & 6.0 \\
5 to 6 Days A Week & 6.6 \\
Less Than 4 Days A Week & 61.7 \\
Not Applicable & 25.7 \\
\hline
\end{tabular}

Table 4 shows the percentage of how often students read the articles on English Islamic websites per week. This table reveals that $61.7 \%$ of the students read the articles less than four days in a week, and only $6 \%$ of them read the articles every day of the week. However, $25.7 \%$ of the students answered that this question is not applicable to them, possibly because they only read the articles once a week or intermittently. The results are related to the following results presented in Table 5 .

Table 5. Frequency of reading English Islamic websites per month

\begin{tabular}{ll}
\hline & Percentage \\
\hline More Than 10 articles in English Islamic Websites & 6.0 \\
7-10 articles in English Islamic Websites & 13.2 \\
4-6 articles in English Islamic Websites & 32.9 \\
1-3 articles in English Islamic Websites & 38.9 \\
Not Applicable & 9.0 \\
\hline
\end{tabular}

Table 5 shows the amount of reading English Islamic websites per month. The results indicate that $38.9 \%$ of the students read 1-3 articles in English Islamic websites, and only 6\% of them read more than 10 articles in a month. However, $9 \%$ of the students stated that this question is not applicable, which is likely because they might not read the articles as frequently.

The results in Tables 6-10 presented below are based on the topic and subthemes that students read most. As mentioned earlier, the topics and subthemes were selected from a collection of Islamic websites that are popular amongst the Muslims who took part in the pilot questionnaire. However, for this study, the respondents were allowed to tick more than once from the topics and subthemes listed. The topics were Personal Relationship, Islamic Studies, Personal Development, Society and Productivity.

Table 6. Topic on personal relationship and subthemes

\begin{tabular}{lll}
\hline \multirow{2}{*}{ Personal Relationship } & \multicolumn{2}{l}{ Percentage } \\
\cline { 2 - 3 } & No & Yes \\
\hline With God & 15.6 & 84.4 \\
Marriage and family & 35.9 & 64.1 \\
With others & 55.1 & 44.9 \\
With brotherhood/sisterhood & 62.9 & 37.1 \\
\hline
\end{tabular}

On the topic of personal relationship, Table 6 shows that the respondents prefer to read about the Relationship with God (84.4\%), while the least read subtheme is on the relationship among brotherhood and sisterhood (37.1\%). Interestingly, despite the respondents' single marital status, the second highest subtheme read by the respondents is on marriage and family (64.1\%), whilst $44.9 \%$ read about gender relations. This could indicate that students turn to the Islamic principles for relationship advice. 
Table 7. Topic on Islamic studies and subthemes

\begin{tabular}{lll}
\hline \multirow{2}{*}{ Islamic Studies } & \multicolumn{2}{l}{ Percentage } \\
\cline { 2 - 3 } & No & Yes \\
\hline Beliefs & 44.3 & 55.7 \\
Qu'ran and Prophet's Traditions & 43.7 & 56.3 \\
Biography of Prophet Mohammad & 68.3 & 31.7 \\
Religious edict & 74.9 & 25.1 \\
Supplication and Prayers & 27.5 & 72.5 \\
\hline
\end{tabular}

Table 7 lists a more formal type of reading related to Islamic studies. Accordingly, the highest subtheme is supplication and prayers (72.5\%), whilst the least read is on religious edict (25.1\%). The second popular subtheme is on the Qur'an and Prophet's traditions (56.3\%), followed closely by beliefs (55.7\%). Meanwhile only $31.7 \%$ read about the biography of Prophet Mohammad.

Table 8. Topic on personal development and subthemes

\begin{tabular}{lll}
\hline \multirow{2}{*}{ Personal Development } & \multicolumn{2}{l}{ Percentage } \\
\cline { 2 - 3 } & No & Yes \\
\hline Motivation & 32.3 & 67.7 \\
Seeking Knowledge & 38.3 & 61.7 \\
Overcoming Hardship & 41.3 & 58.7 \\
Spiritual Purification & 41.3 & 58.7 \\
Reflection & 48.5 & 51.5 \\
Islamic Character Development & 52.1 & 47.9 \\
Grooming & 73.1 & 26.9 \\
\hline
\end{tabular}

On the topic of Personal Development, the results in Table 8 indicate that the respondents' most favourite subtheme is motivation (67.7\%) which reflects their needs as students. The second highest subtheme is seeking knowledge with $61.7 \%$. The respondents $(58.7 \%)$ also read on spiritual purification, or a way of cleansing themselves of sins. The statistics is the same with the theme on overcoming hardship where respondents read texts in search for the best method to deal with problems. Apart from that, $51.5 \%$ of the respondents read materials on reflection, and $47.9 \%$ read about Islamic character development. Grooming, which is related to physical beauty is the least read subtheme $(26.9 \%)$.

Table 9. Topic on society and subthemes

\begin{tabular}{lll}
\hline \multirow{2}{*}{ Society } & \multicolumn{2}{l}{ Percentage } \\
\cline { 2 - 3 } & No & Yes \\
\hline Women & 34.7 & 65.3 \\
Youth & 35.9 & 64.1 \\
Men & 61.7 & 38.3 \\
International Affairs & 67.1 & 32.9 \\
Domestic Affairs & 71.9 & 28.2 \\
Converts & 71.9 & 28.1 \\
\hline
\end{tabular}

Table 9 is on the topic of Society. The results show that $65.3 \%$ of the respondents choose to read about women, followed by the subtheme on youth $(64.1 \%)$. This data supports the demographic of the respondents whereby $75.4 \%$ of the sample population are females aged between 18 to 29 . This explains why the reading trend is skewed heavily towards these two subthemes. Issues on domestic affairs faired the lowest with $28.2 \%$ compared to the subtheme on international affairs (32.9\%). Moreover, only 38.3\% of the respondents read on the subtheme on men, and $28.1 \%$ on converts. The lack of interest reflects the respondents who are mostly Muslim-born females. 
Table 10. Topic on productivity and subthemes

\begin{tabular}{lll}
\hline \multirow{2}{*}{ Productivity } & \multicolumn{2}{l}{ Percentage } \\
\cline { 2 - 3 } & No & Yes \\
\hline Work/Studies & 24.0 & 76.0 \\
Health/Fitness & 52.7 & 47.3 \\
Time Management & 61.1 & 38.9 \\
\hline
\end{tabular}

Table 10 presents the results on the topic of productivity where the results indicate that most of the respondents read about productivity in work and studies (76\%). The second highest subtheme is on health/fitness with $47.3 \%$. Since the subjects are undergraduate students, therefore the trend of reading tends to focus on work or studies. However, only $38.9 \%$ read about time management which is interesting considering that the assumption would be that time management is important for students. Normally, productivity can be increased if time is managed well; however, the data does not support this assumption.

\subsection{Students' Perceptions on the Effects of the Reading Trends and English Islamic Websites}

The following results reflect the respondents' personal opinion towards the effect of reading the topics and subthemes on their personal growth.

Table 11. Students' Perceptions on the Effects of the Reading Trends to their Personal Growth

\begin{tabular}{lc}
\hline Items & Mean \\
\hline In my opinion, after I started reading English Islamic writings on the internet... & \\
\hline my knowledge of Islam has increased & 4.31 \\
my motivation level towards my religion has increased. & 4.26 \\
I am more optimistic towards life. & 4.14 \\
my relationship with God has improved. & 4.08 \\
I find more peace and happiness in my life. & 4.07 \\
my motivation towards my studies/jobs/responsibilities has improved. & 4.01 \\
my life in general has improved. & 3.96 \\
my thinking skills have improved. & 3.95 \\
my relationship with people in general has improved. & 3.91 \\
my character has improved. & 3.90 \\
my relationship with people in my life has improved. & 3.86 \\
my fluency in the English language has improved. & 3.77 \\
\hline
\end{tabular}

Table 11 shows positive results towards the items listed. The highest mean is 4.31 for the item "my knowledge of Islam has increased". Furthermore, 4.26 and 4.14 are the means for the items "my motivation level towards my religion has increased" and "I am more optimistic towards life" respectively. In addition, the means for the items "my character has improved", and "my relationship with people in my life has improved" are 3.90 and 3.86 respectively which are also positive. The results show that the students agree that their character, their relationship with people in general and with the people in their life have improved through reading the Islamic values. Finally, the lowest mean is 3.74 for the item 'my fluency in the English language has improved' means that their English language has improved somewhat after they started reading English Islamic websites. 
Table 12. Students' perceptions on the trends of English Islamic websites

\begin{tabular}{lc}
\hline Items & Mean \\
\hline In my opinion... & \\
\hline more Muslims should read the websites. & 4.44 \\
\hline more should be done to publicise Islamic English websites in Malaysian universities. & 4.44 \\
\hline more should be done to publicise these reading materials in Malaysian schools for Muslims. & 4.43 \\
\hline the writings can be used as teaching materials in religious classes. & 4.34 \\
\hline $\begin{array}{l}\text { the writings can be used as teaching materials in the English language classroom in Islamic } \\
\text { universities. }\end{array}$ & 4.31 \\
\hline the writings can be used as teaching materials in the English language classroom in schools. & 4.24 \\
\hline these articles should be common reading amongst all Muslims. & 4.23 \\
\hline the Islamic writings make understanding Islam easier. & 4.22 \\
\hline the English language used in the websites is an excellent way to spread Islam to non-Muslims. & 4.22 \\
\hline there is a growing trend of reading materials from the English Islamic websites. & 4.16 \\
\hline the English language used in the websites is an excellent way to spread Islam. & 4.14 \\
\hline the English language used in the websites is an excellent source of knowledge for reverts. & 4.11 \\
\hline the English language used in the online writings is simple for me to understand. & 3.98 \\
\hline people who read the English Islamic websites are fluent in the English language. & 3.47 \\
\hline
\end{tabular}

The results presented in Table 12 are related to the students' perceptions on the trends of reading English Islamic websites. The results show that the highest mean is 4.44 which is for the item "more Muslims should read the websites" and "more should be done to publicise Islamic English websites in Malaysian universities". This is followed by 4.43 which is the mean for the item for "more should be done to publicise these reading materials in Malaysian schools for Muslims". This shows that students agree that more Muslims should not only read English Islamic websites but more should be done to publicise these reading materials in Malaysian universities. This is consistent with their view that they enjoy reading it and would want more youngsters to be exposed to the readings. Additionally, the means for the items 'the English language used in the websites is an excellent source of knowledge for reverts' and 'the English language used in the online writings is simple for me to understand' are 4.11 and 3.98 respectively. This means the students are of the opinion that English language used in the websites is a reliable and highly recommended source of knowledge for reverts because the English language used in the online writings are also simple for them to understand. Finally, the lowest mean is 3.47 for the item 'people who read the English Islamic websites are fluent in the English language' which implies that they, as readers, do not consider themselves as fluent in the English language. It also means that the language used is simple enough to attract wide readership regardless of the proficiency. This is also a positive indicator that the English classrooms should be able to accept them as teaching materials because the language and content should appeal to many types and levels of readers' proficiency.

\section{Discussion}

This study posed the following research questions: (1) What are the reading trends of English Islamic websites amongst Malaysian Muslim youths? (2) What are the Malaysian youths' perceptions towards the trends of reading English Islamic websites? and (3) What are their perception of having the English language be taught using materials from the English Islamic websites?

A survey conducted on Malaysian Islamic University students showed that they highly recommend the use of Islamic English reading texts to gain further knowledge, not only for their personal worship and overall understanding of the religion, but also for learning the English language. These students are motivated to read such texts for non-academic purposes. Additionally, the survey also showed that they would like to read more of these materials in the English language in English classrooms. As indicated in the results, the students want to read about motivation and seeking knowledge. This means that more Muslims want readings that are less focused on facts and non-academic texts. They also prefer to read texts that address their personal problems and challenges. This is why the results indicate that they prefer to read about topics pertaining to overcoming hardships and spiritual purification. In addition, they also prefer to read about personal relationship with God and personal relationship in marriage and family. These findings are parallel to a survey by Wischenbart (2011) who found that young adults in United Arab Emirates between the age of 20 and 35 are more interested in reading religious texts which shows that the preference of reading religious texts correlates with age. While the National 
Reading Profile Survey conducted in Malaysia showed that the general Malaysian reading habits are low, this study has proven that Malaysian Muslim students do read, but they are reading from online sources rather than books, especially on topics like personal development and religion. This finding corresponds to the findings that the internet is valued as a supporting reference material for religious texts (Wischenbart, 2011).

This study has thus far argued that more Islamic materials should be recognised and accepted as teaching materials in English classrooms in addition to the Western and secular teaching materials used throughout the Muslim World. By identifying the current reading trends in English among Malaysian youths, the study can draw a conclusion and propose that texts on spiritual knowledge and personal development, read and enjoyed by Malaysian youths in their spare time, are used as reading materials in English lessons for Muslim students. This proposal supports previous studies that state that readings can be more meaningful when students learn more than just English. Students need to want to read about topics that are of interest to them. To improve the reading habits of Malaysians, the initial and developmental stages of reading should be encouraging and pleasurable so that they become passionate and independent readers in the future. This especially applies to non-native students who learn English as a second language. Thus, through exposure to the English Islamic texts, Malaysian Muslims can further improve their English proficiency whilst enhancing their knowledge of the religion. To support the findings from this study, more academics and stakeholders need to pay attention to the importance of promoting such readings, as they too, play a role in influencing reading trends.

It is acknowledged that the strong support for more Islamic-oriented writings is subjected to biases due to the fact that the participants in this study are Muslims learning about Islam at an Islamic institution. This explains why they are more exposed, accepting, and tolerant of both secular and Islamic texts. However, their familiarity with the online Islamic English texts was needed in order to gain valid opinions regarding its content. Thus far, their views have showed strong support that the Islamic English contents are engaging and authentic for use in English classrooms. It lends support to Murray and Mcpherson's (2004) findings that learners are able to learn the language more naturally when they are engaged with texts that are more meaningful. This study has proven that Muslims find it more meaningful when the texts are addressing their needs whilst they learn the English language. In the case of Muslims in Arab countries, the Holy Qur'an and religious texts are considered to be most popular and meaningful texts for reading (Wischenbart, 2011). Thus with a strong need and support for non-secular texts, texts that can enlighten them with positive values and are in-line with the Islamic teachings should be used more. Perhaps in the future, such texts can be used in religious classes taught in the Malay language to form a wider understanding of the religion from the perspective of other Muslims around the world. This then supports the call by Rosnani (2004 as cited in Zaiton \& Hishamuddin, 2012) to make pedagogical methods of teaching Islam fresh and engaging.

\section{Acknowledgements}

The writers would like to express gratitude to Universiti Sultan Zainal Abidin (UniSZA) for funding the research. We would like to also express our gratitude to the IIUM and UniSZA students for participating in this study.

\section{References}

Adam, Z., \& Lallmamode, S. P. (2009). Awareness of Islamic English among Muslim students in Malaysia. SOLLSO9 (pp. 435-451). Retrieved from http://irep.iium.edu.my/7368/

Aliyu, M., Mahmud, M., \& Tap, A. O. (2013). Features influencing Islamic websites use: A Muslim user perspective. Intellectual Discourse, 1(21), 33-54.

Bunt, G. R. (2003). Islam in the digital age: E-Jihad, online fatwas and cyber Islamic environment. London: Pluto Press.

Burns, P. C., Roe, B. D., \& Smith, S. H. (2002). Teaching reading in today's elementary schools. In M. Jafre, Z. Abidin, J. S. P. Low, \& P. Raman (Eds.), Malaysian Journal of ELT Research, 8(1), 119-152.

Ibrahim, E. N. M., Hamzah, W. N. I. I. W., Taslim, J., \& Adnan, W. A. W. (2010). Evaluating trust elements in the context of Islamic based informational websites (pp. 268-272). 2010 International Conference on User Science and Engineering (i-USEr). http://dx.doi.org/10.1109/IUSER.2010.5716764

Ariffin, I. A. M. (2010). Tabiat Membaca Di Kalangan Pelajar Kemahiran Hidup Di Universiti Pendidikan Sultan Idris (Thesis, 2010).

McKay, S. L. (2003). Toward an appropriate EIL pedagogy: Re-examining common ELT assumptions. International Journal of Applied Linguistics, 13(1), 1-22.

Murray, E. D., \& Mcpherson, P. (2004). Using the Web to support language learning. Sydney: Macquarie 
University.

Abidin, M. J. Z., Low, J. S. P., \& Raman, P. (2012). Using web-based resources in reading comprehension in a rural primary school. Malaysian Journal of ELT Research, 8(1), 119-152.

National Library of Malaysia. (2010). Reading profile of Malaysians: 2010. Kuala Lumpur: Perpustakaan Negara Malaysia. Retrieved August 16, 2011, from http://www.pnm.gov.my

Wischenbart, R. (2011). Report of Reading Habits in the United Arab Emirates. Retrieved May 15, 2014, from http://editoriaraba.files.wordpress.com/2012/10/reading-habits-in-the-uae.pdf

Mustafa, Z., \& Salim, H. (2012). Factors Affecting Student's Interest in Learning Islamic Education. Journal of Education and Practice, 3(13), 81-87.

Khairuddin, Z. (2013). A Study of Students' Reading Interests in a Second Language. International Education Studies, 6(11), 160-170.

\section{Copyrights}

Copyright for this article is retained by the author(s), with first publication rights granted to the journal.

This is an open-access article distributed under the terms and conditions of the Creative Commons Attribution license (http://creativecommons.org/licenses/by/3.0/). 